\title{
Pemberdayaan Rema Muda Dalam Membangun Desa Mandiri dan Berjiwa Usaha Melalui Pos Pintar Dalam Meningkatkan Ekonomi
}

\author{
Dajani Suleman ${ }^{1}$, Samsiar Rivai ${ }^{2}$ \\ $1,{ }^{2}$ Universitas Negeri Gorontalo, Jl. Jend. Sudirman No. 6 Dulalowo Timur, Kota \\ Tengah, Kota Gorontalo, Indonesia \\ Email : dajani_suleman@ung.ac.id, samsiar_rivai@ung.ac.id
}

\begin{abstract}
Abstrak
Pemuda merupakan bagian dari masyarakat yang menjadi sendi-sendi bangsa juga perlu untuk dibenahi dengan segala persoalan yang ada. Kegitan pemberdayaan merupakan implikasi dari strategi pembangunan yang berbasis pada masyarakat, termasuk pemuda. Secara sederhana, adanya kegiatan pemberdayaan adalah bagaimana membuat individu yang tidak berdaya menjadi lebih berdaya, artinya pemberdayaan memberikan suatu proses individu untuk mengembangkan kemampuannya supaya lebih berdaya atau berkemampuan. Sehingga upaya pemberdayaan sangat cocok dan potensial diberikan pada kaum muda. Dengan potensi yang dimiliki pemuda, maka pemuda perlu ikut diberdayakan agar lebih mampu dan mandiri mengembangkan dirinya dan bangsanya. Dengan dilakukan pemberdayaan terhadap remamuda desa sehingganya akan mengurangi kesenjangan yang akan muncul terutama kesenjangan social.
\end{abstract}

Kata Kunci : Pemberdayaan, Desa Mandiri, Pos Pintar

\begin{abstract}
Youth is part of society which is the foundation of the nation and it also needs to be addressed with all the existing problems. Empowerment activities are implications of community-based development strategies, including youth. In simple terms, the existence of empowerment activities is how to make a helpless individual become more empowered, meaning that empowerment provides an individual process to develop their abilities to be more empowered or capable. So that empowerment efforts are very suitable and potential to be given to young people. With the potential of youth, youths need to be empowered to be more capable and independent in developing themselves and their nation. By empowering village youth, it will reduce the gap that will arise, especially social inequality.
\end{abstract}

Keywords: Empowerment, Independent Village, Smart Post

(C) 2021 Dajani Suleman, Samsiar Rivai Under the license CC BY-SA 4.0

Correspondence author : Dajani Suleman, dajani_suleman@ung.ac.id, Gorontalo, and Indonesia 


\section{PENDAHULUAN}

Era globalisasi telah melanda hampir seluruh bidang kehidupan manusia di seluruh dunia tidak terkecuali Indonesia. Kemajuan dan perubahan terjadi berjalan beriringan dengan derasnya arus globalisasi. Perkembangan zaman yang sangat cepat seperti sekarang ini menuntut sumber daya manusia mempunyai kualitas yang tinggi untuk mencapai kehidupan yang lebih sejahtera. Seperti ungkapan Umberto Sihombing (2001:73) yang menyatakan bahwa ketersediaan sumber daya manusia yang berkualitas dan memiliki keunggulan kompetitif sangat diperlukan untuk memasuki era baru, karena setiap daerah akan berlomba untuk memantapkan keberdayaan daerahnya menuju kemakmurann masyarakatnya.

Peranan generasi muda sebagai penggerak dan penyegar tetap diperlukan dalam masa pembangunan. Namun peranan generasi muda dalam sosialisi bermasyarakat sungguh menurun dratis, dulu biasanya setiap ada kegiatan masyarakat seperti kerja bakti, acara-acara keagamaan, adat istiadat biasanya yang berperan aktif dalam menyukseskan acara tersebut adalah pemuda sekitar. Pemuda sekarang lebih suka dengan kesenangan, selalu bermain-main dan bahkan ketua RT/RW nya saja dia tidak tahu. Banyak pemuda yang lebih senang merantau keluar daerah sehingga pemuda di desa sangat sedikit. Di masa perkembangan ini, karena pengaruh penyalahgunaan teknologi mengakibatkan kenakalan remaja yang meningkat, tawuran pemuda, penggunaan narkotika dikalangan pemuda dan sebagainya. Di samping itu keterbatasan lowongan kerja menyebabkan banyaknya pengangguran di kalangan pemuda membuat pemuda menjadi malas untuk melakukan sesuatu. Apalagi keterampilan yang dimiliki pemuda 
yang masih kurang menyebabkan banyaknya pengangguran. Ini merupakan tantangan yang harus dihadapi oleh pemuda di masa perkembangan ini.

Maka dari itu dibutuhkan generasi muda yang tetap terus menempa dirinya menjadi pribadi-pribadi yang memiliki intelektual, kreatif, percaya diri, inovatif dan memiliki kesetiakawaan sosial dan semangat pengabdian terhadap masyarakat, bangsa dan negara yang tinggi. Membuka peluang usaha diharapkan mampu mengurangi banyaknya pengangguran. Dengan semangat yang dimiliki pemuda seharusnya mampu melihat peluang dan mewujudkan pembangunan nasional. Karena dalam pembangunan memerlukan kecermatan perhitungan, kesadaran dan kelincahan usaha, ketepatan penilaian dan pemilihan objek pembangunan, persiapan dan perencanaan yang sungguh-sungguh serta memerlukan kegiatan-kegiatan yang kreatif dan produktif bukan destruktif.

Untuk itu dibutuhkan masyarakat dalam hal ini rema muda kecamatan buntulia desa buntulia utara agar dapat membangun/membina desa mereka menjadi desa mandiri dan berjiwa usaha melalui kemampuan/skill yang mereka peroleh. Dimana desa mandiri yang dimaksud adalah mencerminkan kemauan masyarakat desa yang kuat untuk maju, dihasilkannya produk/karya Desa yang membanggakan dan kemampuan desa memenuhi kebutuhankebutuhannya.

Dalam istilah lain, desa mandiri bertumpu pada trisakti desa yaitu; karsa, karya, sembada. Jika Trisakti Desa dapat dicapai maka desa itu disebut sebagai desa berdikari. Karsa, karya, sembada desa mencakup bidang ekonomi, budaya dan sosial yang bertumpu pada tiga daya 
yakni berkembangnya kegiatan ekonomi desa dan antar Desa, makin kuatnya sistem partisipatif desa, serta terbangunnya masyarakat di Desa yang kuat secara ekonomi dan sosial-budaya serta punya kepedulian tinggi terhadap pembangunan serta pemberdayaan desa.

Agar dapat menjadi sebuah desa mandiri dan berjiwa usaha maka salah satu cara yang harus dilakukan adalah dengan memberdayakan masyarakat dalam hal ini rema mudanya. Dimana pemberdayaan masyarakat desa adalah adalah proses pembangunan di mana masyarakat berinisiatif untuk memulai proses kegiatan sosial untuk memperbaiki situasi dan kondisi diri sendiri. Masyarakat desa yang terpinggirkan baik secara sosial, ekonomi dan politik dan miskin di identifikasi dengan mata pencaharian sebagai nelayan dengan pendapatan rendah. Tujuan pemberdayaan masyarakat desa merupakan upaya untuk mengurangi kemiskinan, memperkuat integrasi sosial sebagai komitmen bersama untuk kesejahteraan masyarakat dan ketahanan sosial. Metode pemberdayaan masyarakat desa melalui pembinaan potensi dalam rangka ketahanan sosial dilakukan melalui sinergitas program antar lembaga baik pemerintah maupun swasta dengan memperhatikan kondisi sosial masyarakat.

Adapun cara pemberdayaan masyarakat kecamatan buntulia desa buntulia utara melalui pembentukan pos pintar. Dimana pos pintar ini yang akan menampung semua ide tentang kreativitas yang ada dalam rangka mewujudkan desa mandiri dan berjiwa usaha. Akan tetapi selama ini disetiap desa masyarakat dalam hal ini jarang dimanfaatkan oleh pemerintah setempat dalam membangun/meningkatkan ekonomi desa. Jika dimanfaatkan itupun hanya dalam kegiatan tertentu saja. Untuk itu melalui kegiatan pengabdian KKN tematik ini, bersama 
mahasiswa dan masyarakat akan membentuk satu organisasi berupa pos pintar.

\section{METODE PELAKSANAAN}

Metode pelaksanaan kegiatan ini adalah melalui sosialisasi pemberbadayaan masyarakat dalam pembentukan organisasi/kelompok pos pintar sebagai salah satu cara untuk meningkatkan ekonomi warga masyarakat kecamatan buntulia desa buntulia utara kabupaten pohuwato. Kegiatan ini akan dilakukan dengan tahapan sebagai berikut :

\section{A. Persiapan dan Pembekalan}

Mekanisme persiapan dan pembekalan kegiatan KKN tematik dapat dirinci sebagai berikut.

1. Survey lokasi KKN tematik pengabdian pada masyarakat oleh pihak UNG

2. Koordinasi dengan camat/pemerintah setempat oleh pihak UNG

3. Koordinasi dengan Desa tempat mahasiswa tinggal

4. Perekrutan mahasiswa peserta koordinasi dengan LPPM-UNG

5. Pembekalan (Coaching) dan pengasuransian mahasiswa

6. Penyiapan sarana dan prasana yang dibutuhkan dalam pelaksanaan kegiatan KKN tematik -Pengabdian.

7. Pelepasan mahasiswa peserta KKN tematik Tahap II oleh kampus UNG.

8. Pengantaran 32 orang mahasiswa peserta KKN tematik Tahap II ke lokasi.

9. Penyerahan peserta KKN tematik Tahap II ke lokasi oleh panitia ke pemerintah setempat 
10. Monitoring dan evaluasi awal dan pertengahan periode kegiatan KKN tematik Tahap II

11. Monitoring dan evaluasi akhir kegiatan KKN tematik Tahap II

12. Penarikan mahasiswa peserta KKN tematik Tahap II

\section{B. Uraian Program KKN Tematik}

Adapun uraian materi/program persiapan dalam membekali mahasiswa peserta KKN tematik Pengabdian meliputi :

1. Peran dan fungsi mahasiswa dalam program $\mathrm{KKN}$ tematik Pengabdian.

2. Panduan dan pelaksanaan program KKN tematik Pengabdian.

3. Materi sosialisasi pemberbadayaan masyarakat dalam hal ini rema muda desa dalam pembentukan organisasi/kelompok pos pintar menuju desa mandiri dan berjiwa usaha sebagai salah satu cara untuk meningkatkan ekonomi masyarakat.

4. Konsep sosialisasi pemberbadayaan masyarakat dalam pembentukan pos pintar yang akan diberikan kepada mahasiswa.

5. Pengenalan model-model kegiatan yang akan dikelola didalam kelompok pos pintar.

6. Pelaksanaan tahapan kegiatan KKN tematik Tahap II tahun anggaran 2020.

7. Pembentukan pengurus kelompok pos pintar menuju desa mandiri dan berjiwa usaha yang ada di kecamatan buntulia desa buntulia utara.

8. Pelantikan pengurus kelompok pos pinta yang ada di kecamatan buntulia desa buntulia utara. 
9. Pendampingan oleh mahasiswa kepada warga masyarakat kecamatan buntulia desa buntulia utara dalam pemanfaatan pos pintar

\section{Rencana Aksi Pelaksanaan KKN Kemaritiman}

Pelaksanaan pengabdian yang terintegrasikan dalam KKN tematik yang dilakukan oleh Dosen dan mahasiswa adalah sosialisasi pemanfataan kembali cangkang kerang yang meliputi: (1) Observasi, (2) Pemberian materi, (3) pelaksanaan kegiatan pembuatan/pendirian pos pintar.

Tabel 3.1. Aktivitas Kegiatan Pengabdian Dosen Terintegrasi dalam KKN Tematik Tahap II

\begin{tabular}{|c|c|c|}
\hline No & Langkah Kegiatan & Aktivitas Kegiatan Yang Dilakukan \\
\hline 1 & Observasi & $\begin{array}{l}\text { a. Fasilitas sosialisasi } \\
\text { pemberbadayaan masyarakat } \\
\text { rema muda dalam } \\
\text { pembentukan kelompok pos } \\
\text { pintar sebagai salah satu } \\
\text { alternatif dalam meningkatan } \\
\text { ekonomi masyarakat buntulia } \\
\text { desa buntulia utara }\end{array}$ \\
\hline 2 & $\begin{array}{l}\text { Pemberian Materi } \\
\text { Sosialisasi tentang } \\
\text { pemberdayaan } \\
\text { masyarakat (karang } \\
\text { taruna) masyarakat } \\
\text { buntulia desa buntulia } \\
\text { utara }\end{array}$ & $\begin{array}{l}\text { a. Penjelasan tentang pentingnya } \\
\text { menjaga kebersamaan } \\
\text { b. Pentingnya pengetahuan } \\
\text { tentang memanjukan ekonomi } \\
\text { masyarakat } \\
\text { c. Penjelasan tentang jenis-jenis } \\
\text { kegiatan yang dapat }\end{array}$ \\
\hline
\end{tabular}




\begin{tabular}{|c|c|c|}
\hline & & $\begin{array}{l}\text { meningkatkan ekonomi } \\
\text { masyarakat melalui } \\
\text { pembentukn pos pintar } \\
\text { d. Penjelasan tentang pengolahan } \\
\text { kelompok pos pintar dalam } \\
\text { meningkatkan ekonomi } \\
\text { masyarakat kecamatan buntulia } \\
\text { desa buntulia utara } \\
\text { e. Penjelasan tentang kegiatan } \\
\text { yang akan dilakukan oleh warga } \\
\text { masyarakat kecamatan buntulia } \\
\text { desa buntulia utara dalam pos } \\
\text { pintar tentang berbagai jenis } \\
\text { kreativitas } \\
\text { f. Penjelasan tentang desa } \\
\text { mandiri } \\
\text { g. Pentingnya tentang masyarakat } \\
\text { berjiwa usaha } \\
\text { h. Penjelasan tentang pos pintar } \\
\text { i. Pelantikan pengurus kelompok } \\
\text { Pos Pintar. }\end{array}$ \\
\hline 3 & $\begin{array}{l}\text { Pelatihan berbagai jenis } \\
\text { kreativitas melalui } \\
\text { pemanfaatan pos pintar } \\
\text { oleh mahasiswa peserta } \\
\text { KKN tematik kepada } \\
\text { masyarakat (karang }\end{array}$ & $\begin{array}{l}\text { a. Menyediakan alat dan bahan } \\
\text { b. Melakukan pendampingan } \\
\text { kepada warga masyarakat } \\
\text { kecamatan buntulia desa } \\
\text { buntulia utara dalam kegiatan } \\
\text { berbagai kreativitas yang dapat }\end{array}$ \\
\hline
\end{tabular}




\begin{tabular}{|l|l|l|}
\hline & taruna) & $\begin{array}{l}\text { meningkatkan ekonomi } \\
\text { masyarakat. }\end{array}$ \\
\hline
\end{tabular}

\section{HASIL DAN PEMBAHASAN}

\section{Hasil}

Kreativitas adalah kemampuan menciptakan dan mewujudkan gagasan baru untuk meningkatkan nilai tambah atau manfaat dari bahan-bahan yang sudah tersedia. Krativitas sangat dibutuhkan dalam upaya membuka lapangan kerja baru karena kreativitas sebagai suatu acuan utama dalam memperoleh suatu pekerjaan yang layak bagi kehidupan mendatang. Kreativitas juga menentukan pola pikir dan karakter seseorang. Tidak ada hewan yang memiliki kemampuan mencipta seperti yang manusia miliki. Kreativitas memiliki peranan yang sangat penting karena memberikan berbagai manfaat bagi kehidupan manusia. Kreativitas memberikan andil yang sangat besar dalam setiap kesuksesan. Berikut ini adalah beberapa manfaat kreativitas dalam kehidupan sehari-hari: meningkatkan keunggulan kompetitif, meningkatkan produktivitas, mengatasi masalah, mengatasi kegagalan, mengatasi kebosanan.

Berkaitan dengan kreativitas, mahasiswa KKN Kecamatan Buntulia Desa Buntulia Utara Kabupaten Pohuwato dibawah bimbingan Dra. Dajani Suleman, M.Hum. dan Dra. Samsiar Rivai, S.Pd., M.Pd. melakukan kegiatan pengabdian pada masyarakat dengan tema Pemberdayaan Rema Muda Dalam Membangun Desa Mandiri dan Berjiwa Usaha, dimana kegiatan mahasiswa KKN yang berkerjasama dengan karang taruna desa buntulia utara ini membuat satu kegiatan kreativitas yakni pemanfaatan kembali handuk bekas, karpet bekas 
menjadi pot bunga. Akan tetapi sebelum kegiatan tersebut dimulai, mahasiswa KKN desa buntulia utara mengadakan rapat kecil yang membahas kegiatan yang dimaksud. Dimana pada rapat tersebut dihadiri oleh kepala desa buntulia utara, sekertaris desa, kepala dusun, ketua karang taruna, pengurus karang taruna, beberapa orang dari warga masyarakat dan mahasiswa KKN sendiri.

Dalam pelaksanaan rapat tersebut dibahas mengenai jadwal pelaksanaan kegiatan, penunjukkan panitia kegiatan dan pembentukan pengurus POS PINTAR yang merupakan program unggulan dari KKN Tematik UNG Desa Buntulia Utara Kabupaten Pohuwato. Disamping itu juga pada rapat tersebut membahas pemateri yang akan memaparkan sedikitnya tentang wirausaha yang akan mengajarkan kepada karang taruna/rema muda desa buntulia utara dalam berkreasi memanfaatkan bahan bekas menjadi bahan yang bermanfaat guna meningkatkan ekonomi desa meningat sekarang masih masa pandemic Covid-19 sehingga sangat sulit untuk memperoleh pekerjaan. Oleh karena itu diharapkan para rema muda yang tergabung dalam pengurus karang taruna agar memiliki keterampilan, kreativitas dalam memanfaatkan berbagai macam benda untuk/guna menunjang perekonomian keluarga maupun desa. Keterampilan juga sangat diharapkan dimiliki oleh semua orang, mengingat sekarang masih masa pandemi covid-19 yang kesemuanya sangat sulit untuk diperoleh.

Berdasarkan hasil rapat tersebut kegiatan sosialisasi tentang pembentukan POS PINTAR sekaligus demo kreativitas oleh mahasiswa KKN akan dilaksanakan tepatnya pada Poskesdes (Posyandu Kesehatan Desa) pada hari Kamis, 17 September 2020 Pukul 09.00 s/d selesai. Pada kegiatan tersebut akan dibuka oleh Kepala Desa Buntulia 
Utara Bapak Jardin Saleh, Ketua Karang Taruna Fendi Hulopi, Kepada Dusun Kenari I, dan para tamu undangan lainnya. Dalam kegiatan sosialisasi tersebut akan membahas tentang bagaimana membuat kreativitas dari bahan bekas yakni handuk, karpet dan gelas aqua bekas serta bagaimana cara mengelola hasil kreativitas.

\section{Pembahasan}

Sejatinya Revolusi Industri 4.0 adalah tren otomatis dan pertukaran data terkini dalam teknologi, istilah ini mencakup sistem siber fisik, internet of things. Saat ini, masyarakat Indonesia secara tidak langsung udah memasuki revolusi ini. Dengan semakin berkembangnya revolusi industry 4.0, maka akan semakin diwajibkan juga sumber daya manusia di Indonesia yang dituntut semakin kreatif. Tidak banyak yang tahu bahwa kreativitas sebenarnya membuat seseorang menjadi lebih baik karena cenderung menghasilkan sesuatu yang unik dan dapat mengubah perspektif kita. Kreativitas memungkinkan untuk melihat kehidupan dari sudut pandang yang berbeda sehingga dapat membantu memecahkan masalah.

Kreativitas dan inovasi mempunyai peranan yang penting dalam menjalankan sebuah bisnis. Seringnya banyak kesuksesan yang didapat oleh pebisnis diawali dengan kreativitasnya menemukan inovasi pengembangan produk bisnisnya. Daya kreativitas tersebut selayaknya dilandasi dengan cara berpikir yang maju, ide baru, dan berbeda dibandingkan produk-produk yang telah ada. Jika pebisnis mampu memaksimalkan kreativitas untuk melahirkan sebuah inovasi, maka bisnis yang dikelola akan mampu pula tampil berbeda dibandingkan dengan bisnis serupa lainnya. 
Seringnya orang keliru memahami arti kreatif dan inovatif. Dua hal ini cukup berbeda walau saling berkaitan. Kreativitas adalah kemampuan untuk mengembangkan ide-ide baru dan untuk menemukan cara-cara baru dalam melihat masalah dan peluang. Sedangkan inovasi adalah kemampuan untuk menerapkan solusi kreatif terhadap masalah dan peluang untuk meningkatkan atau untuk memperkaya kehidupan orang-orang. Jadi kreatif adalah sifat yang selalu mencari cara-cara baru dan inovatif adalah sifat yang menerapkan solusi kreatif. Kreatif tapi tidak inovatif menjadi siasia karena ide hanya sebatas pemikiran tanpa ada tindakan nyata.

Untuk itu tujuan diadakannya kegiatan sosialisasi mengenai POS PINTAR dimana yang untuk memberikan sedikit pengalaman kepada masyarakat khususnya karang taruna desa buntulia utara bagaimana cara mengolah bahan bekas berupa karpet bekas ataupun handuk bekas untuk dijadikan bahan kerajinan tangan berupa pot bunga sederhana. Adapun tujuan pembuatan POS PINTAR ini adalah dimana masyarakat yang memiliki berbagai ide kreatif akan dibahas pada pos pintar, nantinya pengurus pos pintar yang telah dibentuk yang akan membahas seperti apa nantinya prosesnya dan akan dikelola Bersamasama dengan warga masyarakat khususnya dalam hal pembuatan dan penjualan.

Adapun kegiatan mahasiswa KKN Tematik tahap 2 tahun 2020 desa buntulia utara selain sosialisasi tentang kreativitas pengolahan barang bekas ada juga, kegiatan pembagian masker yang dilakukan Bersama apparat kepolisian setempat, kemudian pembuatan kebun TOGA, pembuatan taman mini dihalaman poskesdes yang dijadikan sebagai tempat posko KKN Tematik, pembagian stiker tentang Covid- 
19, sosialisasi ke rumah-rumah warga masyarakat tentang bagaimana pencegahan Covid-19, membimbing anak-anak warga masyarakat yang dalam tingkatan SD untuk bagaimana cara belajar daring dengan memanfaatkan jaringan internet, sampai pada pembuatan papan pembatas dusun permanen serta taman percontohan desa buntulia utara yang bekerjasama dengan perusahaan yang ada di kabupaten pohuwato.

Pentingnya kreativitas atau kemampuan berpikir kreatif dalam kaitannya dengan upaya peningkatan mutu pendidikan memang sangat logis, dimana kemampuan berpikir kreatif dianggap sebagai sumber yang amat vital bagi suatu bangsa. Oleh karena itu sistem pendidikan (formal, nonformal, informal) hendaknya ditujukan untuk mengembangkan kualitas berpikir anak agar dalam proses perkembangan kognitif dan inteligensinya memperoleh peluang secara optimal pula.

Oleh karena itu memiliki kreativitas sangat penting oleh semua masyarakat tidak hanya buntulia utara, akan tetapi seluruh warga masyarakat. Dalam kehidupan ini kreativitas sangat penting, karena kreativitas merupakan suatu kemampuan yang sangat berarti dalam proses kehidupan manusia. Ada beberapa nilai penting kreativitas dalam kehidupan secara nyata sebagai berikut (Suprapti, 2010) :

a) Adanya kemampuan untuk melahirkan sesuatu yang baru yang berupa pikiran maupun karya nyata dalam mengerjakan persoalan hidup bagi orang kreatif. Dengan kreatifnya seseorang dapat melakukan pendekatan secara bervariasi dan memiliki bermacammacam kemungkinan penyelesaian terhadap suatu persoalan. Dari potensi kreatifnya, seseorang dapat menunjukkan hasil perbuatan, 
kinerja/karya, baik dalam bentuk barang maupun gagasan secara bermakna dan berkualitas.

b) Tingkat kualitas dari kinerja, karya, gagasan, dan perbuatan manusia dapat diantisipasi dari sejauh mana seseorang memiliki tingkat kreativitas tertentu.

c) Suatu karya kreatif sebagai hasil kreativitas seseorang dapat menimbulkan kepuasan pribadi yang tak terhingga nilainya. Kreativitas penting untuk mengembangkan semua bakat dan kemampuan individu dalam pengembangan prestasi hidupnya.

d) Dengan kreativitas tinggi yang dimiliki seseorang maka seseorang tersebut akan mempunyai pengembangan diri secara optimal. Mereka dapat mempergunakan ide-idenya untuk menciptakan kreasi baru demi kelangsungan hidup.

e) Kreativitas penting untuk dipahami bagi para pendidik (guru) terutama dalam kaitannya dengan tugas dan tanggung jawabnya sebagai pendidik dan pengajar dalam membimbing dan "mengantarkan" anak didik kepada pertumbuhan dan perkembangan prestasinya secara optimal.

f) Peningkatan Sumber Daya Manusia dalam era globalisasi dan era reformasi menunjukkan betapa pentingnya segi kreativitas diprioritaskan untuk dikelola dan dikembangkan secara optimal. Dan hal ini merupakan tantangan kepedulian serius bagi pihak terkait dalam pengembangan Sumber Daya Manusia, terutama dikalangan pendidikan.

g) Akan lebih bermakna dalam tugas perkembangannya bagi para pelajar, apabila pengelolaan, pengembangan dan peningkatan kreativitas mencakup potensi akademik dan non akademik. Dengan 
itu, potensi-potensi kreatif siswa akan dapat tersalur dan teraktualisasi secara optimal.

h) Kreativitas penting dalam proses belajar mengajar, terutama bagi guru. Guru diperlukan kemampuan untuk menciptakan suasana yang menyenangkan dan kondusif agar siswa terangsang untuk lebih ingin mengetahui materi, senang menanyakan, dan berani mengajukan pendapat, serta melakukan percobaan yang menuntut pengalaman baru. Hal ini penting bagi guru dalam kegiatan belajar mengajar dengan harapan agar siwa mendapat kesempatan untuk mengukir prestasi secara optimal.

i) Kreatif sebagai operasionalisasi dari konsep kreativitas yang mempunyai nilai penting dalam kehidupan individu. Conny $R$. Semiawan (dalam Reni Akbar hawadi, dkk, 2001:15) menyatakan ada empat alasan penting mengapa seseorang perlu belajar kreatif, antara lain:

1) Belajar kreatif membantu anak menjadi lebih berhasil guna jika kita (orang tua/guru) tidak bersama mereka.

2) Belajar kreatif menciptakan kemungkinan-kemungkinan untuk memecahkan masalah yang tidak mampu kita duga yang akan timbul di masa depan.

3) Belajar kreatif menimbulkan akibat yang besar dalam kehidupan seseorang, dapat mempengaruhi, bahkan dapat mengubah karir pribadi serta dapat menunjang kesehatan jiwa dan badan seseorang.

4) Belajar kreatif dapat menimbulkan kepuasan dan kesenangan yang besar. 
Secara lebih luas, belajar kreatif dapat menimbulkan terciptanya ide-ide baru, cara-cara baru, dan hasil-hasil yang baru. Pada kegiatan KKN Tematik ini diharapkan dengan adanya pembentukan POS PINTAR ini akan muncul berbagai macam ide kreatif dari pemuda karang taruna desa buntulia utara. Dari kegiatan mahasiswa KKN Tematik Tahap 2 desa buntulia utara menghasilkan luaran berupa terbentuknya POS PINTAR yang dibuktikan dengan SK kepala desa serta kegiatan inti dari KKN ini dimuat pada berita online yang dapat dilihat pada laman berikut https://dulohupa.id/bantu-perekonomian-ditengah-pandemi-covid-19-kkn-ung-latih-masyarakat-mendaur-ulangbarang-bekas/ selain itu juga hasil akhir dari pada KKN Tematik ini atau laporannya akan dimuat pada jurnal http://ejurnal.ung.ac.id/index.php/sibermas/issue/view/479.

\section{KESIMPULAN}

Pembangunan dan pemberdayaan desa diharapkan mampu melahirkan pertumbuhan ekonomi yang berkualitas dan berkelanjutan. Pertumbuhan ekonomi yang berkualitas adalah konsep mengenai perkuatan dan kontribusi yang disumbangkan oleh sektor ekonomi riil. Sektor ekonomi riil yang tumbuh dan berkembang dari bawah karena dukungan ekonomi rakyat di desa. Pertumbuhan ekonomi dari bawah bertumpu pada 2 hal pokok yakni memberikan kesempatan seluasluasnya kepada pelaku ekonomi lokal untuk memanfaatkan sumberdaya milik lokal dalam rangka kesejahteraan bersama dan memperbanyak pelaku ekonomi untuk mengurangi faktor produksi yang tidak terpakai. Oleh karena itu dalam memajukan ekonomi desa pesisir khususnya kecamatan buntulia, dibutuhkan masyarakat dalam hal ini 
rema muda yang berjiwa usaha menuju desa mandiri. Untuk memenuhi semua itu diperlukan salah satu cara agar rema muda kecamatan banggai bisa menciptakan desa mandiri dan berjiwa usaha dengan cara membentuk pos pintar sebagai wadah mereka untuk memajukan desa mereka.

\section{UCAPAN TERIMA KASIH}

Ucapan terima kasih kami Team Pengabdian ucapkan pertama, kepada kepada bupati kabupaten pohuwato,camat buntulia, pemerintah desa buntulia utara, yang telah bersedia menerima mahasiswa KKN UNG selama kurang lebih 45 hari, kemudian terima kasih kepada Rektor Universitas Negeri Gorontalo yang telah memberikan kepercayaan kepada kami Team Pengabdian untuk melaksanakan tugas pengabdian pada masyarakat, terima kasih juga kepada bendahara yang telah mendanai kegiatan pengabdian kami, dan teristimewa kepada mahasiswa UNG sebagai peserta KKN Tematik UNG yang selama 45 hari kerja berada dilokasi desa buntulia utara dalam menyelesaikan kegiatan KKN.

\section{REFERENSI}

Novitasari Nesa. 2013. Pemanfaatan Barang Bekas. http://nesanovitasari.blogspot.com/2013/03/pemanfaatanbarang-bekas.html. Diakses tanggal 13 November 2020 Pukul 11.55 WIB

Suprapti Novi. 2010. Pentingnya Kreativitas Dalam Kehidupan. https://www.kompasiana.com/novi suprapti/550052e5a33311 5c735107bf/pentingnya-kreativitas-dalamkehidupan\#: :text=Dalam\%20kehidupan\%20ini\%20kreativitas \%20sangat,berarti\%20dalam\%20proses\%20kehidupan\%20m anusia.\&text=Adanya\%20kemampuan\%20untuk\%20melahirk 
an\%20sesuatu,persoalan\%20hidup\%20bagi\%20orang\%20kre atif. Diakses Tanggal 15 November 2020 Pukul 14.51 WITA.

Suryadi Edi. 2026. Pentingnya Kreativitas Dalam Meningkatkan Mutu Pendidikan.

http://edisuryadi.staf.upi.edu/2016/02/16/pentingnya-

kreativitas-dalam-meningkatkan-mutu-pendidikan/. Diakses tanggal 13 November 2020 Pukul 17.19 WIB.

Totok M dan Poerwoko S. 2013. Pemberdayaan Masyarakat (Dalam Perspektif Kebijakan Publik). Bandung. Alfabeta.

Umberto Sihombing. 2001. Pendidikan Luar Sekolah (Masalah, Tantangan dan Peluang). Jakarta. Wirakarsa.

Wibowo W. Lendi. 2016.

https://risehtunong.blogspot.com/2016/01/konsep-desamandiri.html. diakses tanggal 21 Januari Pukul 22.06 WIB.

https://desaduwetblog.wordpress.com/manfaat-kuliah-kerja-nyata-kkn/.

Diakses tanggal 22 Januari 2020 Pukul 10.46 Wita 